\title{
To Win the War, You Fought it Sideways: Kojo Laing's Major Gentl and the Achimota Wars
}

Kodwo Eshun

...toffee tougher for all, toughest for the sweetest
war of all.

LAING 1992: 54

\section{THE LAINGIAN TEXT}

Major Gentl and the Achimota Wars, the third novel written by novelist and poet Kojo B. Laing, in 1992, following his celebrated debut Search Sweet Country (1986), his second novel Woman of the Aeroplanes (1988), Godhorse (1989), his first volume of poetry, and preceding his fourth and final novel Big Bishop Roko and the Altar Gangsters (2006), is the most sustained science fiction yet written in which the futurity of the African continent constitutes the object and the stake of warring forces. Laing narrates the struggle for the right to invent futurity as a war for and over the future existence of the continent. The First and Second Wars of Existence, which play out at the level of the city-state of Achimota, dramatize a technological struggle to determine the direction of the future. Laing envisions the year 2020 as an era in which one power fights for the right to project themselves into a futurity from which they will be expelled by the victory of their enemy. The distinction between 'futurity' and the 'future' draws upon Hugh Charles O'Connell's useful distinction between the 'future' as the 'qualitative aspect' of the quotidian passing of time, 'futurity' as the "qualitative notion of the future as difference" and the 'future' that is reduced by the conditions of capitalist realism to the "merely quantitative notion" of the "extension or intensification of the conditions of the present" (2016: 292). In Major Gentl and the Achimota Wars, the Achimotans fight to defend the "novum" or the newness of their Afropolitan futurity against Africa South's effort to capture their qualitative futurity as a resource for their quantitative future. Instead of an ongoing imposition of capitalist realism that reduces the quali- 
tative notion of futurity as difference to the merely quantitative notion of the future, Laing depicts a universe in which the actually existing condition of the future as novum provokes South Africa to dedicate itself to extracting the qualitative novelty of Achimotan futurity as a quantitative resource. The Laingian universe is enacted in and by an extraordinary 'inventivism' of syntax, grammar, and mode of address, ${ }^{1}$ each of which is subjected to the same process of technological acceleration that engenders the experimental city of Achimota. As Miriam Pahl suggests, Major Gentl and the Achimota Wars constitutes nothing less than a War of Existence waged in and on the front of contemporary African literature characterized by the realist histories of the Anglophone African novel typified by the Heinemann African Writers Series, sustained in academic journals, and consolidated by African literature departments in African, European and American universities (Malec 2017). Rereading reviews of Major Gentl and the Achimota Wars throughout the 1990s indicates the extent to which the Laingian text frustrated the modes of critical interpretation that previously welcomed Search Sweet Country as a breakthrough in African literature. ${ }^{2}$ Major Gentl and the Achimota Wars performs the same act of disestablishmentarianicism upon the critical expectations of African literature ${ }^{3}$ that Achimota City enacts upon its allies and its adversaries:

"When the elders were talking about money to finance the new strategies, Jojo Digi blew his nose very loudly, nostril finance, and insisted that there was too much linear thinking. After which the compromise was that the golden cockroach and Government Crow should strike up an alliance, the object of which was to loosen things up a bit and to treat all established relationships as unsacred, some disestablishmentarianistic cockroach and crow.” (1992: 128)

1"For Simondon's thought to resonate, constructivism has to make room for an integral inventivism (if such a word exists). An inventivism that is not afraid of nature, and its creativity" (Massumi et al. 2009: 38).

${ }^{2}$ Brenda Cooper argues that "Set as science fiction in the year 2020 in a place called Achimota City, its chapters are called 'Zones'. In this novel, Laing has, I think succumbed to the pleasures and linguistic devices and philosophical riddles and paradoxes to the extent of creating a fiction that is almost unreadable" (1998: 213).

3 As Pietro Deandrea puts: "Genre definitions become increasingly difficult...is this another case of fantastic realism - a further projection of Stephen Slemon's conception of magic realism where enabling strategies for the future require revisioning the seemingly tyrannical units of the past in a complex and imaginative double think of 'remembering the future' or the first example of African science fiction?" (1996: 172). See also Tobias Robert Klein: "Laing's prose is such a rich variety of poetic yet culturally bound gargantuan images, motifs, puns and witty humour that it confidently defines reduction to a single larger theory, agenda or narrative" (2007: 38). 
Mr Cee the golden cockroach and Government Crow's first act of disestablishmentarianicism begins with a flight to the glass house owned by Pogo Alonka Forr, Achimota City's playboy-millionaire, war financier, and weapon manufacturer: First of all, they ordered the foundations of the house to cease being foundations for things were different; but the order had to be rescinded for Pogo was livid that his glass house was shaking, and had indeed thrown a frozen oval carrot around the duo to freeze their actions." (ibid: 129).

Pogo Forr is not an adversary. He is a critical ally whose fortune funds the new weapons used by Achimota City. Nonetheless, Mr Golden Cockroach and Government Crow escalate their unsettling action by demanding to know whether Forr's weaponized carrots will "fit into the general strategies as elements of defence or attack" (ibid) to which Pogo retorts "I don't need an elevated insect and a dirty crow questioning the very foundations of my life..." (ibid: 131). The duo's calculated insolence confounds the line of command that organizes the War of Existence. Pogo Forr's offended response indicates the ways in which the cockroach and the crow's command acts as a 'lever of intervention' ${ }^{4}$ that shakes the relations established between the ground and the house and the three characters until it threatens to unground the "very foundations" of Pogo Forr's life. Major Gentl and the Achimota Wars conducts a similar process of disestablishmentarianicism upon the 'realist' conventions of 'African literature', the effect of which is to confront critical interpretation with the recursive question of the existence of African literature. What are its preconditions of existence? How, and in what ways, is its Africanity instituted? What grounds the literarity of Africanity? Such questions can be concentrated upon African literature's conceptualization of 'futurity' as it is engendered and sustained by a restricted system of predicates. Africa's future, Africa's futurity, Africanity's future, Africanity's futurity, Futurity's Africa, Future's Africanity, Future's Africa, Futurity's Africanity: these terms are not so much concepts or metaphors or concept-metaphors as "systems of predicates that define concepts" (Derrida 1982: 71). Laingian disestablishmentarianicism works in and on and by way of the systems of predicates that define the concept of futurity that are operative in the fields that go by the names of magical realism, Afrofuturism, African science fiction, ${ }^{5}$ African speculative fiction, Afropolitanism, Pan-Africanism, which is under-

${ }^{4}$ Derrida writes “...the name $\mathrm{X}$ being maintained as a kind of lever of intervention, in order to maintain a grasp on the previous organization, which is to be transformed effectively" (1982: 71).

${ }^{5}$ Moradewun Adejunmobi defines African science fiction in terms of "African authors use of sf (science fiction) elements to interrogate the sociopolitical arrangements that inform the African condition in the current age" (2016: 265). 
stood here as a futurist project of continental unification, ${ }^{6}$ the denominated genre of EuroAmerican science fiction, global science fiction, and science fiction qua science fiction. Instead of asserting the right of Major Gentl and the Achimota Wars to belong to the generic territories that nominate themselves as science fiction, the Laingian text could be said to pose a problem and a possibility for science fiction qua science fiction. Instead of integrating the Laingian text into the canon of African science fiction or belatedly admitting it into the canon of Afrofuturism, perhaps a more generative procedure would be to think with the ways in which a Laingian grammar reorganizes the predicates that compose the 'futures' and 'futurities' of science fiction. In doing so, it might indicate ways of reconfiguring the ground, the stakes and the object of the 'future'. Thinking with Major Gentl and the Achimota Wars might indicate a method for mobilizing a movement of thought that mobilizes a capacity for becoming or ontogenesis that exceeds science fiction qua science fiction. Such an ontogenetic poetics is already mobilized in and by the Laingian text. To think with Major Gentl and the Achimota Wars as a problem and a possibility for the thought of the future in this way entails a debt to Nahum D. Chandler's formulation of the practice of 'desedimentation' that works on the "ontological problematization of existence, in discussions of the question of the Negro or Negro American as a problem for thought, certainly of discourse and knowledge, but also of historical existence in general" (2014: 353-354). ${ }^{7}$ Desedimentation here refers to "a kind of labor of desedimentation that would mobilise, that is disturb the lability of the shifts and fault lines that configure the ground that surrounds them" (2014: 354).

The Golden Cockroach and the Government Crow have already conducted "a kind of labor of desedimentation" on the foundations of Pogo Forr's glass house. Their order shakes the grounds of Forr's house that surrounds them. Their 'labor' is

\footnotetext{
${ }^{6}$ See George Padmore: "And all the national units comprising the regional federations shall be autonomous in all matters regional, yet united in all matters of common interest to the African Union. This is our vision of the Africa of Tomorrow - the goal of Pan Africanism" $(1956,276)$. The project of continental unification proposed by George Padmore in PanAfricanism or Communism: The Coming Struggle for Africa in 1956, Kwame Nkrumah in Africa Must Unite in 1963 and by Cheikh Anta Diop (1987) in Towards an African Energy Doctrine in 1960 each argue in their distinct ways for a post-national future assembled in and through an African Union.

${ }^{7}$ Desedimentation, Chandler writes, yields “ “.. a destabilization of ground, field or domain, a movement that could expose sediment that had been deeply locked and fixed in place or set into relief new lines of possible concatenation or turn up old ground into new configurations of its elements" (2008: 353-354). See also Nahum Dmitri Chandler, $X$ - The Problem of The Negro as A Problem for Thought, Fordham University Press New York 2014, pp. 11-68.
} 
undertaken in the confounding manner that characterizes the ludicrous work of disestablishmentarianicism. The ontological problematization of existence is already underway, conducted in the exhaustive inventivism of ontological slapstick. Disestablishmentarianicism adds the letters $i c$ to the preexisting term disestablishmentarianism. ${ }^{8}$ The 'ic' does not cancel its historical predicate; instead it formulates a neologism that retains and reconfigures its "old ground into new configurations of its elements" (Chandler 2014: 354).

The disestablishing capacity of the Laingian text to confound critical expectations coupled with the lack of a critical vocabulary for its sheer inventivism begins to account for its absence from Black Sci-Fi, ${ }^{9}$ the documentary produced for the BBC in 1992, from Mark Dery's interview-essay "Black to the Future: Interviews with Samuel R. Delany, Greg Tate and Tricia Rose" in 1994, and from The Last Angel of History in $1995 .{ }^{10}$ Laing's work poses a problem for the ways in which Afrofuturism understands itself, a challenge that critics have, until recently, found themselves unable to come to terms with. ${ }^{11}$ Imagine, however, a parallel version of The Last Angel of History also directed by John Akomfrah for Black Audio Film Collective that included scenes from an interview with Kojo B. Laing, discussing Major Gentand the Achimota Wars, filmed in a studio on Oxford Street, Accra.

${ }^{8}$ Laing's reworking of the term alludes to disestablishmentarianism as a process of terminating the established status of the Church of England by severing its official connection to the state thereby leading to the uncoupling of the monarchy from the church. The Archbishop of Canterbury would no longer crown the new monarch in the ceremony of coronation and the monarch would no longer be the Supreme Governor. The figure of the Archbishop of Canterbury who "arranged his dreams through Catholic thrillers and intrigues ....and through biscuits invaded by tiny ants" plays a critical role in Laing's final novel Big Bishop Roko and the Altar Gangsters, Woerli Books, 2006, pp. 1.

9 The documentary Black Sci-Fi featured Octavia E. Butler, Samuel R. Delany, Nichelle Nichols, Steven Barnes directed by Terrance Francis was broadcast on BCC 2 in 1992. See Dukan (n.d.).

${ }^{10}$ See Laura U Marks (2015).

${ }^{11}$ See Geoff Ryman: "The 1996 film The Last Angel of History (by John Akomfrah and written and researched by Edward George of Black Audio Film Collective) is a mightily influential film, credited with helping to establish the concept of Afrofuturism in people's minds. But it makes no mention of Kojo Laing, even though Woman of the Aeroplanes had been published in 1988 and Major Gentl and the Achimota Wars appeared in 1992... The terms needed to describe Laing's work did not exist at that time - and probably still don't. Even if Afrofuturism had become more established, better enabling the reception of his work, I don't think Laing is a futurist of any kind. He's not writing science fiction (unless you use SF so loosely it means any kind of fantastic literature)" (2017: n.p.). 
These imaginary sequences would have to enter into dialogue with the existing filmed sequences depicting Octavia E. Butler discussing the stakes of the Xenogenesis Trilogy, 1987-1989, and Samuel R. Delany analyzing the aesthetico-political valence of Dhalgren, 1975. The presence of Laing might, in turn, imply the renarration of the scenes that depict the distant coastline of Ghana filmed from the perspective of the Atlantic Ocean, the scenes depicting crowded Ghanaian streets and the archival sequence of Kwame Nkrumah waving a white handkerchief, standing in a white state car, slowly moving through crowds of young Ghanaians. Each of these scenes, which are named as episodes from "The Land of African Memory" would have to be renamed as "The Land of African Futurity". Such a brief thought experiment merely hints at the extent to which the presence of Laing articulates a project of Ghanaian futurity whose implications would enter into and reconfigure the figuration of futurity elaborated in and by The Last Angel of History. The aim of this imaginary exercise is neither to find 'fault' with nor to 'correct' The Last Angel of History or the Black Sci-Fi documentary or the writings of Mark Dery for excluding the work of Laing. Instead, it is intended as a gesture that begins to articulate the realignment of the thought of Afrofuturism that is set in motion by and through an encounter with the Laingian cosmos.

But the doubt persisted: shouldn't they save this city alone and damn the rest of the country?

LAING 1992:106

\section{IN THE VOID OF THE POSTCOLONY}

The "Author's Note on the Glossary" that initiates Major Gentl and the Achimota Wars directs attention towards the list of 155 terms printed after the novel's conclusion. Each term, whether Hausa or Ga or Akan, comes from a language that will be spoken by the inhabitants of Achimota City in 2020. The words are drawn from a language from a future city that is transcribed and alphabetically sequenced in the present of 1992 in order to encourage its emergence in the future. The glossary works by announcing a language of and from a future as an already achieved outcome in the present:

"world of Major Gentl and the Achimota Wars. The motive behind them is to internationalize the English. I believe that more parochial areas of the world need a broadening of vocabularyhence many of the words are repeated in my novels and poetry. Some are invented, most are direct translations from Akan and Ga and sometimes Hausa. It is usual in Ghana (with such a cosmopolitan mix of cultures) to intersperse one language with words from another. This 
ought to be done universally for the idea is to create one gigantic language." (Laing 1992: n.p.)

By compressing, expanding and interspersing Akan, Ga, English, Italian, Hausa and Ghanaian English words, Major Gentl and the Achimota Wars enacts and encourages the exponentially converging tendency towards "one gigantic language." The forms of speech that will be spoken by the Achimotans in the year 2020 exemplify the expansion of an actually existing Ghanaian cosmopolitanism. Laing envisions Achimota City as the prototype for a city of the future. Its universalizing ethos prefigures the Afropolitan condition that would be characterized six years in the future by Achille Mbembe as the:

"presence of the elsewhere in the here and vice versa, the relativisation of primary roots and membership and the way of embracing, with full knowledge of the facts, strangeness, foreignness and remoteness, the ability to recognize one's face in that of a foreigner and make the most of the traces of remoteness in closeness, to domesticate the unfamiliar, to work with what seem to be opposites." (2007: 28)

For Mbembe, it is the city of Johannesburg that epitomizes a South African cosmopolitanism that draws upon its "relativisation of primary roots" to affirm a civic ethos of tolerance that will "revive African aesthetic and cultural creativity, in the same way as Harlem or New Orleans once did in the United States" (ibid: 29). The Achimotans of 2020 endorse the tenets of strangeness, foreignness and remoteness in the full knowledge that they themselves embody these qualities. Achimota City's anomalous metropolitanism emerges in and through the inexplicable disappearance of the nation state of Ghana. The government elder Jojo Digi demands to know “WHERE IS THE REST OF THE COUNTRY?" (Laing 1992: 71) but neither he nor anybody else mentions Ghana by name at any time. The City's existence is predicated on the void of the postcolony. Its aesthetic of inventivism presupposes the ongoing "relativisation" of the "primary roots" of a people whose understanding of belonging is no longer premised upon the existence of a nation the limits of which have ceased to function (Mbembe 2007: 29). The figure of Flight Lieutenant John Jerry Rawlings' Provisional National Defence Council that ruled the Republic of Ghana in 1991 is nowhere to be found in the novel. Instead, Achimota City is ruled by a Council of "three elders of government, each with a beard the shape of X, Y or Z" (Laing1992: 3). This political body spends its time debating whether their City is better off without or with the country whose name they no longer recall. Achimota City expands until it incorporates the capital of Accra and the port of Tema. The citizens design the City as a total work of art crowded with "fruit in the 
toilets, fruit in the halls and fruit in the aeroplanes, so that you could eat the city" (ibid). ${ }^{12}$ The fruitarian architecture of Achimota City hosts a political "system of rotating leadership" that allows "every adult, and a few children, too, the chance to be head of state for months, weeks or even minutes" (ibid). The exuberant abundance of the "truncated city" (ibid) draws the envious attention of Azania. The Achimotans regard the future planned by the 'bosses' of South Africa's 'rich cities' (ibid: 7) with the pity reserved by the gods of Valhalla for the schemes of mankind. In his introductory essay to Search Sweet Country, Binyavanga Wainaina characterizes the novel's multitudinous characters as "types that the city of Accra manufactures" (1986: xii). The city-state of Achimota has manufactured a new humanity of "an advanced type" (Laing 1992: 175) that is united by its contempt for Africa South. The Second War of Existence is waged against Achimota City by Africa South's proxy, Torro the Terrible aka The Torro aka Torro the Gorro. Torro is a thick-necked, fat-cheeked, beef-eating Italian ex-mercenary who arranged to be born in South Africa "for the second time after a shortish life of robbery and lechery in Rome..." (ibid: 114) He lives in Achimota City with Bianca, his longsuffering South American wife and their son Commander Carlo, always accompanied by his faithful rats. His protuberant belly resembles the "smooth side of a snake" (ibid: 33) and his weaponized erection resembles a "pink personal torpedo" (ibid: 151). He screams, shouts and threatens in a ridiculous Italian roar "Major, you are always tougher than I theenk! Now, to show you how serious I am, I am pronto breenging you your coffin in advance for you to taste how nice death is before I keel you, no!” (ibid: 154).

Small moths come "out of his anus" (ibid: 34 ) when he is especially angry and the "tall kwee" of his farts force butterflies from his anus with a "warm abandon" (ibid: 143, 141). Torro's unpredictable temper tantrums threaten to derail his masters' long term plans for Achimota City which are closely monitored by the Achimotans that observe his actions, discuss his intentions, track the intelligence broadcast from Africa South's radio stations and triangulate their observations with their inferences.

\footnotetext{
${ }^{12}$ It is this fruitarianist urbanism that provides the starting point for Nikhil Singh's graphic story for Major Gentl and the Achimota Wars. See The Chronic: The Corpse Exhibition and other Graphic Stories August 2016.
} 
Torro hadn't computed that in wars of existence bullets could fire their guns.

LAING 1992: 171

\section{MiLITARIZING AFRICAN LIFE}

Achimota City is an isolated exception. The Pan-Africanists of Abdourahman Waberi's In the United States of Africa (2009) in contrast to the Laingian year 2020, speak from an undated future in which the United States of Africa has become a political reality. Its narrator speaks in the patriotic and patronizing tone of a tour guide from a world of actually existing Pan-Africanism:

"From its business center in Massawa or its online stock market on Lumumba Street, not to mention the very high-tech Keren Valley Project and the military-industrial complexes in Assab, everything here works together for success and prosperity. This is what attracts the hundreds of thousands of wretched Euramericans subjected to a host of calamities and a deprivation of hope." (2009: 5) ${ }^{13}$

In the military industrial complexes of the port city of Assab on the West Coast of Eritrea, George Padmore's 1956 futuristic "vision of the Africa of Tomorrow" in which "all the national units comprising the regional federations shall be autonomous in all matters regional, yet united in all matters of common interest to the African Union" (ibid: 276) has become a political fact, acknowledged by the immiserated hordes of "wretched Euramericans" forced to emigrate to the African continent. The Pan-Africanist science fiction of Waberi extrapolates from Padmore and Nkrumah's federalist futurism that theorizes continental unification as the process of deterritorialization of the nation-state whose "territorial boundaries... are the relics of colonialism". As Moradewun Adejunmobi argues, it is precisely the unrealized technoscientific promise of the United States of Africa that attracts the speculative extrapolation of Waberi and renders Pan-Africanist history available for con-

13 The narrator continues: "Still more dizzying is the flow of capital between Eritrea and its dynamic neighbors, who are all members of the federation of the United States of Africa, as is the former Hamitic kingdom of Chad, rich in oil; and also the ex-Sultanate of Djibouti that handles millions of guineas and surfs on its gas boom; or the Madagascar archipelago, birthplace of the conquest of space and tourism for the enfants terribles of the new high finance" (Waberi 2009: 5). 
temporary fabulation. ${ }^{14}$ In the borderless future of the African Union envisioned by Nkrumah in 1963, national boundaries "will become obsolete and superfluous" ${ }^{15}$ In Laing's year 2020, however, Nkrumah's plan for the "major political union of Africa" has inverted and imploded into the superhybridised termite urbanism of Achimota City. The City fights without support from the other cities of the countries of the continent. It is sequestered from Nkrumah's African Union which has seemingly been rendered "obsolete and superfluous" by the "new ways that the century demanded" (1992: 3). Only after the final battle of the Second War does Major Gentl hear that "South Africa was free, and had established links with cities of all sorts in Africa" (ibid: 179-180). What are the new ways demanded by the new century? Achimota City is obliged to defend its future against an enemy whose only aim is to prevent it from planning its future. Africa South's plan is to extend its project of apartheid into the genetic commons of human DNA and the farthest reaches of the universe. It is to pioneer a future of cosmogenetic segregation that begins with "stealing intellectual energy to burst out of the galaxy" and concludes with the prospect of "biological changes to augment the barriers they have put around themselves physically" (ibid: 135). Faced with the calamitous prospect of a total War of Existence, the city turns towards the defense of its realm. The prospect of the total mobilization of the city by the state takes on an urgent necessity. Such a position was articulated two years before the birth of the nation of Ghana in 1955 by Richard Wright in Black Power: A Record of Reactions in a Land of Pathos. As the Gold Coast's Convention Peoples Party prepared to take over political institutions from the departing British empire, Wright addressed Nkrumah, the Party's leader in a letter, arguing that:

14 "To start with, the power and promise of technoscience are rarely realized in the African postcolony. But this might be the reason why for a growing number of African authors, representations of functioning technologies belong more so in the realm of speculative fictions than in realist works, whether such fictions address the future, or adopt a backwards glance, seeking to create $[\ldots]$ a 'speculative history"' (Adejunmobi 2016: 256).

15 "Under a major political union of Africa there could emerge a United Africa, great and powerful, in which the territorial boundaries which are the relics of colonialism will become obsolete and superfluous, working for the complete and total mobilization of the economic planning organization under a unified political direction" (Nkrumah 1963: 221-222). Nkrumah's emphasis on rendering "obsolete and superfluous", the "territorial boundaries" which are the "relics of colonialism" prefigures Mbembe's argument that "In so far as African states are pure (and, what is more, recent) inventions, there is, strictly speaking, nothing in their essence that can force us to worship them" (2007: 29). The sacrilegious impulse towards the nation attributed by Mbembe to Afropolitanism in fact belongs to PanAfricanism. 
“AFRICAN LIFE MUST BE MILITARIZED!...not for military dictatorship but for the militarization of the daily, social lives of the people; I'm speaking of giving form, organization, direction, meaning, and a sense of justification to those lives... a temporary discipline that will unite the nation, sweep out the tribal cobwebs, and place the feet of the masses upon a basis of reality...The ideological justification for such measures is simple survival; the military is but another name for fraternalization, for cohesiveness." $(2008: 417)^{16}$

According to Wright, only militarization was capable of manufacturing the urban masses of the Gold Coast into the industrial proletariat required to build the new state of Ghana. Wright insisted that the institutional transfer of power exceeded the public ceremony of the lowering and raising of old and new flags. ${ }^{17}$ Instead, institutional transfer marked a moment of political instability that could better be understood as a state of emergency. ${ }^{18}$ Major Gentl and the Achimota Wars can be read in dialogue with Black Power: A Record of Reactions in a Land of Pathos. The political danger of the era before, during and immediately after the existence of the new nation in 1955 is rethought from the perspective of the danger faced by the new city after the negation of the nation in 2020 . The demand for a system of mobilization

${ }^{16}$ Wright continued, "Over and above being a means of production, a militarized social structure can replace, for a time, the political; and it contains its own form of idealistic and emotional sustenance" (Wright 2008: 417). See also Frederic Jameson (2016: 69).

17 "The paradox of Nkrumah's ambition was to modernize and ancientize at the same time. And so on emerging into independence the Gold Coast as we have indicated, first decided to wear the ancient name of Ghana- and then embarked on an attempt to modernize the country as rapidly as possible" (Mazrui 1969: 206).

${ }^{18}$ Wright's survivalist argument was reformulated by Julius Nyerere on the eve of independence for Tanganyika in 1961: "New nations like Tanganyika are emerging into independence as a result of a struggle for freedom from colonialism. It is a patriotic struggle which leaves no room for differences, and which unites all elements in the country; and the nationalist movements having united the people and led them to freedom must inevitably form the first government of the new states. Once the first free government is formed, its supreme task lies ahead: the building up of the country's economy, so as to raise the living standards of the people; the eradication of disease; and the banishment of ignorance and superstition. This, no less than the struggle against colonialism, calls for the maximum united effort by the whole country if it is to succeed. There can be no room for difference or division. In Western democracies, it is an accepted practice that in times of emergency opposition parties sink their differences and join together in forming a national government. This is our time of emergency, and until our war against poverty, ignorance, and disease has been won, we should not let our unity be destroyed by a desire to follow somebody else's book of rules." (1997: 158). 
capable of operating in the Global Cold War of the 1950s is reimagined as a speculation on universal conscription for the War of 2020. The militarization of the "daily, social lives of the people" is extended into the preposterous conscription of all species. The fraternal future envisioned by Wright is re-envisioned as a universal army of crawling, flying, defecating and urinating creatures that wage a "beak and claw war" led by an officious golden cockroach and an obsequious silver mosquito (Laing 1992: 140). A war in which platoons of crows pull out the "white Azanian eyes" from twenty of Torro's soldiers (ibid: 139) and rivers divert their "intelligent water power" (ibid: 167) against "Roman soldiers fighting on behalf of France, Germany, Japan, America, Britain and South Africa" (ibid). A war in which crabs join claw to claw in the "shape of aeroplanes with taped drones so false that Torro was sure that such an elementary trick could not have any reality behind it" (ibid: 140). A war in which bullets fire their own guns, leaving "the bullets still in the hands of those who fired and the guns themselves stuck grotesquely in Torro's men..." (ibid: 171). As its name indicates, the Second War of Existence not only entails the compulsory militarization of all species. Its ultimate object and stake is existence qua existence. Existence itself is that which is to be struggled over. ${ }^{19}$ The Second War of Existence does not take place in but beyond existence. The War exists outside of existence as such. A War to determine the right of existence to exist could not be more necessary for the future of the future. And yet Laing depicts the technology of warfare in Major Gentl and the Achimota Wars as a matter of ontological slapstick in which bullets remain "in the hands of those who fired while "the guns themselves" remain "stuck grotesquely in Torro's men" (1992: 171). The bullet that fires the gun that embeds itself in the bodies of Torro's mercenaries exemplifies the substitution of subjects by objects and the inversion of causes by effect operative during the War of Existence. Temporality, causality, logic, and gravity function according to unearthly criteria that entail a reordering of grammar. As Derek Wright perceptively argues, Laing carries out operations of:

"metaphorical displacement and reallocation of qualities and functions to which they do not properly belong. The effect of this is to suspend normal sense-relations and perceptual pro-

${ }^{19}$ See Groys, The Total Art of Stalinism: "The positive and negative heroes of Stalinist culture are the two faces of the preceding avant-garde demiurge and they transcend the reality they create or destroy. Likewise, the struggle between them takes place not within but beyond the sphere of the real, and reality itself is merely a stake in the game. There is no place in avant-garde aesthetics for demonstrating this struggle because it is waged outside the total aesthetic project that embraces the entire world." (2011: 62). See also Boris Groys' chapter "Educating the Masses: Socialist Realist Art" in Art Power, The MIT Press, Cambridge Massachusetts London England 2008: 141-149. 
cesses and to produce a kind of behavioural synaesthesia in which beards 'disagree', people 'eat' thoughts and 'wear' each other's features, and smiles detach themselves from their owners and move according to their own momentum." (1997: 197)

The Laingian operations of displacement and reallocation are not metaphorical; they constitute the grammar of predicates unbound from possession by the 'self'. Laing depicts predicates in the process of becoming entities. Existence is subjected to an ontological disorientation that is narrated in a mode of inexhaustible plenitude. The astonishing extent to which ontological buffoonery is sustained throughout the Second War of Existence can be understood as a process in which being or ontology undergoes a continuous process of becoming or ontogenesis. An ontogenesis that continually engenders ludicrous beings and implausible entities whose existence far exceeds mere humanity. Entities such as the Ship of Truth, the "wrecked sister of the golden cockroach" (Laing 1992: 155) and the chief dog of war that arrives on the battlefield to roar "Allow me to bite you all!" (ibid: 171). The behavior of these creatures appears illogical as long as they continue to be judged by the "earthly criteria" that organizes what counts as the realism of reality. The Second War of Existence only appears absurd according to the earthly criteria of realism that is assiduously desedimented by Laingian grammar thereby engendering the ontological instability that criticism names 'magical realism' (Gaylard 2005: 161, 186). ${ }^{20}$ What is at stake in Major Gentl and the Achimota Wars is not so much a specific genre, as a process of ontogenesis that exceeds all genre and which is narrated in an exorbitant grammar of becoming "ludicrum" (Laing 1992: 71).

Why were the moon and the sun supporters of this city?

LAING 1992: 175)

\section{MAGIC REALISM AS DICTATORSHIP}

And yet, on first reading, magical realism appears to offer the most precise account of the genre of the Laingian text. What, after all, could be more 'magical' than the figure of the golden cockroach, observing, thoughtfully, that the "city is ripening now" as it inhales from its "sikadillo cigar with a small guava stuck at the end of it" (Laing 1992: 2)? Or the description of Major Gentl renting "two rooms on the moon" to which he travels by banging a "nail in the nearest airship" and "holding

${ }^{20}$ See also Brenda Cooper, Magical Realism in West African Fiction: Seeing with a Third Eye, London: Routledge, 1998. 
on tight" until he gains "access to the deepest craters" (ibid: 1)? Laing even uses the word 'magic' to describe the binoculars used by Gentl "to see far into other countries" (ibid). The term 'magic', which appears to conclusively demonstrate that $\mathrm{Ma}$ jor Gentl and the Achimota Wars is indeed a text of postcolonial magical realism, can be rethought by way of Boris Groys' genealogy of 'aesthetic dictatorship'. ${ }^{21}$ Thinking of magical realism in this way usefully revises the term's tendency to consolidate the prior authority of the 'West' as a "single entity confronting innumerable local traditions" (Wenzel 2014: 211-225). According to Groys, the Communist avant-garde movements of Constructivism, Suprematism and Socialist Realism, which opposed each other on ideological grounds, nonetheless shared the deeply held belief that the "knowledge of and especially participation in the murder of God" imbued the avant-garde artist with a "demiurgic, magical power over the world" (2011: 64). This occult understanding of the sacrilegious criminality of the avant-garde invested the term 'magical' with the esoteric valence of the 'Gnostic demiurge'. The idea of the 'magical' entailed the 'hidden' understanding that the avant-garde constituted its own political religion with its own ideology, program and forms of knowledge. Groys argues that the artistic and literary movements of Magical Realism, Surrealism, Socialist Realism and National Socialist art practiced during the 1930s and 40s inherited the Soviet belief in the figure of the artist as a demiurge capable of the creative destruction of existence. Socialist Realism and National Socialist Art understood the nation-state to be a total work of art that could be destroyed and recreated under the vision of the political leader. Magical Realism and Surrealism understood the avant-garde as a project of aesthetic dictatorship exercised over the future of art that could in turn be understood as the prototype for the society of the future. Aesthetic dictatorship, as its name suggests, imbues the avant-garde artist with the power not just to critique or to support the political condition but to actively participate in the realization of the total state machine by treat-

${ }^{21}$ Groys' formulation of magical realism as aesthetic dictatorship differs from Wenzel's cogent critique of the role played by magic in the literary genre of magic realism. Wenzel argues that "the relationship between realism and magic tends to be read as a binary opposition between the West and the rest, between a singular European modernity and multifarious worldviews variously described as pre-modern, pre-scientific, pre-Enlightenment, nonWestern, traditional, or indigenous, or, in more recent and subtly patronizing formulations, alternatively or globally modern... The cumulative effect of such strangely binarist readings of magical realism - in which one term is always the same, the other always different - is the consolidation of the West as a single entity confronting innumerable local traditions. This reification of the West seriously undermines claims for magical realism's subversive, antihegemonic, or decolonizing thrust” (2014: 217). See also Jennifer Wenzel (2014) and Peter Wollen (1999). 
ing art as a practice of crafting or visualizing the total image, imagery, and imaginary of the state.

The tradition of aesthetic dictatorship analyzed by Groys restricts itself to the European avant-garde as it emerged within the totalitarian political systems of the 1920s, 30s, 40s, and 50s. Groys' writing fails to account for the extent to which the belief in the sacrilegious powers of the artist as demiurge extended far beyond Europe's avant-garde. It fails to think the movement of the practice of aesthetic dictatorship in the contexts of the African and the Latin American continents. Focusing on the African novel points towards the figure of the male avant-garde novelist that writes from and with and against the dictatorships of the continent during the 1950s, $60 \mathrm{~s}, 70 \mathrm{~s}, 80 \mathrm{~s}$, and $90 \mathrm{~s}$. The novelistic practice of aesthetic dictatorship is characterized by the personification of the political religion of predatory Pan-Africanism in the figure of the dictator who is depicted as a diabolic artist who subjects existence to his thaumaturgical powers. In the fictions of Marechera and Labou Tansi, life under dictatorship is lived in a disorienting state of ontological vertigo. In the writings of wa Thiong'o and Kourouma, the dictator subjects the body politic of the nation to a continuous destructive creation. The figure of the Providential Guide of Katamalanasia in Sony Labou Tansi's Life and a Half (1979), the Chief in Dambudzo Marechera's Black Sunlight (1980), Koyaga, the President-dictator of the Republique du Golfe in Ahmadou Kourouma's Waiting for the Wild Beasts to Vote (2001), the Ruler of the Free Republic of Aburĩria in Ngũgĩ wa Thiong'o's Wizard of the Crow (2006), and President Houphouet-Boigny of the Ivory Coast in V.S. Naipaul's The Crocodiles of Yamoussoukro (1984) all wield the malefic magic of the state. The Laingian text relocates the source of ontological vertigo outside of its monopoly within the predatory sovereignty of the Tansian or the Kourouman despot. It inverts Marechera's indictment of African dictatorship by multiplying demonic sovereignty throughout its universe. It is from the "emptiness" of the nation state (Laing 1992: 175) that the Laingian figure emerges, bearing its demiurgic capacity to dictate the time and the location of its own birth. Major Gentl arranges to be "born at a particular place, leading his mother from the womb to give birth to him among the pendant-guinea corn in the north" (ibid: 3-4). Torro the Terrible "was born in Italy, but arranged through intrigues in the womb to be born again in South Africa" (ibid: 7). Nana Mai the Grandmother Bomb possesses the power of "bearing her mother back" by "traversing a mighty and wonderful pregnancy to give birth to her own mother in just two hours after herbs had fertilized her" (ibid: 45). The polynymic demiurges of Achimota City possess the power to personify themselves in forms that fail to cloak their otherworldliness. What critics describe as 'magical realism' in Major Gentl and the Achimota Wars could be re-described as a fiction of ontogenesis that narrates "reality itself" as "merely a stake in the game" (Groys 2011: 61-2) to be played by unearthly entities that personify their passions in the physiognomies of multiple species. 
...to win the war, you fought it sideways.

LAING 1992: 175)

\section{Some Problematic Emblem}

It is not for nothing that Major Gentl and the Achimota Wars begins with an act of impossible incarnation. Mr Cee, the emblem of the missing nation's flag "sheds its symbolic nature" to become a "real city cockroach" that crawls about "from one corner of the national flag to another" looking for truth (Laing 1992: 1). Having animated itself, its first act, perversely enough, is to refuse to leave its flag. In his analysis of the role of the Tricoleur in France's military intervention into Mali in 2013, Tom Holert argues that the national flag, understood as a concrete material thing and as abstract symbol is "only interesting in its relationality, as a thing among things, an actant among actants" (2014: n.p.). In leaving its flag, the golden cockroach becomes a very important thing whose self-importance is inversely proportionate to its size. The miniaturism of $\mathrm{Mr}$ Cee is an experimental device that continually trains its interlocutors to assess the scale and the significance of the cosmos within which it operates. ${ }^{22}$ It is a warning device whose existence alerts the Achimotans to the existential threat posed by the rich overseas cities. It is the "problematic emblem" (Laing 1992: 3) of a nation reported missing and presumed stolen. What are the many names of the Golden Cockroach? Mr. Cockroach. Mr Cee, the golden crawl. The golden cee. The golden cockroach with the "smallest shoes that couldn't be seen, that had a red ribbon on its head and a tama around its non existent waist" (ibid: 13). The roachcock. The golden crawler. This crawling emblem, some emblematic problem, some problematic emblem, the sun glinting on its nose, whaaaat. Mr Cockgold. Golden Cee. Mr Goldcrawl. The golden emblem. Roach-the-cock. Dear Cee. Mr Cee the Golden. The eternal crawler.

As it flies from one confidential meeting to another, consulting with the Council of Elders, discussing weapons with Nana Mai and issuing instructions to Major Gentl, each encounter weaves an esprit de corps that binds the City into the "resilient width" (ibid: 174) envisioned as 'cohesiveness' by Richard Wright. The Wars of 2020 have advanced beyond direct military combat into "indirect but lethal" combat (ibid: 138). Mr Cee proceeds by researching the short-term tactics, medium range strategies, and future plans of the enemy. The task of anticipating the enemy's plans

\footnotetext{
${ }^{22}$ See Claude Levi-Strauss: "The intrinsic value of a small-scale model is that it compensates for the renunciation of sensible dimensions by the acquisition of intelligible dimensions" (1966: 24).
} 
falls upon its wings. Its role is to spy upon the enemy's broadcasts, interpret Torro's rages, weigh the gap between the former and the latter, triangulate the outcome, and then relay its decision to Major Gentl, Nana Mai, Pogo Alonka Forr, and Elder One Chairman Kofi Kot, Elder Two Jojo Digi, and Elder Three Amos Kittoe. The chain of command is complicated by Torro's hidden "energy stealing brain machines" (ibid: 6) that extracts energy from Ama Three leading her to join Torro in the fight against Major Gentl. Ama Three's defection to the side of the enemy incites their sons mMo and Aba Y to appoint themselves junior Commanders in the "abofra war" (ibid: 54) waged against their sister Adu who supports her mother and Torro's son Commander Carlo. The children's war is supervised by the mustachioed General Jollof, head of the peacekeeping force that spends its days on the battlefield, "watching the war, listening to radios, and distributing carrots" (ibid: 9). As Jolloff gives orders to his deputy Captain Owusu, Bianca, who has persuaded herself to "have a tiny passion" (ibid: 35) for the General, looks at his moustache upon which she "would desperately want to sit" (ibid). These attachments and interdependencies bind the Achimotans to each other in networks of opportunistic alliances and sudden defections that compose the infrastructure of the City. In Search Sweet Country, as Wainaina points out, "we are left with the feeling that we are dealing not with the fate of individuals but the moving life of a whole city. The characters are merely parts of the city, as the roads and bridges are" (1986: xii).

Even the most minor character ponders the infrastructural implications of their actions in relation to their intentions. The "inner and outer life" of each character noted by Wainaina in Search Sweet Country (1986: xii) has developed into intricate "infrastructures of feeling, ${ }^{23}$ that are fabricated in the "glare of the crisis" of the City (Laing1992: 3). Achimota's streets evoke the boulevards of the Project for the Kinshasa of the $3^{\text {rd }}$ Millenium (1997), and the Ville Fantome (1996) designed by Bodys Isek Kingelez (in Enwezor and Okeke-Agulu 2009: 182) whose elaborate perspectives imply the viewpoint of a Congolese humanity from a future in which

23 The notion of an 'infrastructure of feeling' extends Raymond Wiilliams' formulation of 'structure of feeling' as "social experiences in solution, as distinct from other social semantic formations which have been precipitated and are more evidently and more immediately available" (1977: 133-134). See also AbdouMaliq Simone: "African cities are characterized by incessantly flexible, mobile, and provisional intersections of residents that operate without clearly delineated notions of how the city is to be inhabited and used. These intersections, particularly in the last two decades, have depended on the ability of residents to engage complex combinations of objects, spaces, persons, and practices. These conjunctions become an infrastructure - a platform providing for and reproducing life in the city" (2004: 407-408). 
the affective perception of the intelligible dimensions of the projective city converges with the cognitive map of its sensible dimensions.

How many fronts do you fight a war on?

LAING 1992: 72

\section{The NeW Triple VieW}

Mr Cee provides Major Gentl with a special pair of "magic binoculars" that function as a "two-way spy machine" (Laing 1992: 69). To use them to "see abroad", however, means that "abroad sees you" (ibid). The two-way spy machine loops the Achimotan user into a circular causality in which they look at Azanians looking at them ad infinitum. The 'magic' of the binoculars can be re-described in the vocabulary of cybernetics that elaborates upon the temporal implications of feedback. The Golden Cockroach has anticipated this feedback process. With "its mouth open over the bristle", it explains to the Elders that it has "inverted the superfluous feedback, so that the double viewing was cut off by the new triple view" (ibid). Mr Cee has invented a technical advantage that allows its user to see the effect of being seen by the enemy before the enemy sees him in the act of seeing them. The "new triple view" (ibid) allows the two-way spy machine to function as a prediction device. When Mr Cee explains the new technical advantage to the Council of Elders, he emphasizes the way in which the predictive principle of the "triple view" develops into the preemptive principle of the "third decision": "You see, in life I AM AFTER THE TRIPLE VIEW! samia. I carry this principle in the war: take a third decision immediately you suspect that someone has taken a second one against you secretly" (ibid).

The third decision preempts the enemy's decision. Mr Cee's explanation elucidates the ontology of the enemy (Galison 1994) that has characterized the cybernetic logic of armed conflict since the Second World War and which persists in the Second War of Existence. In the theatre of war, the military decision has to anticipate the consequences of its enemy's decision and control the outcome of that decision by causing it first. The role of the Golden Cockroach is to train the Achimotans to think from the predictive perspective of the triple view and to act according to the preemptive logic of the third decision. Practicing preemption presupposes the ability to see one's 'self' in the third person. Major Gentl and Mr Cee's role is to educate the City into the third decision. The seventeen zones of Major Gentl and the Achimota Wars narrate the stages by which Achimota City's universal army gradually learns to perceive itself from the perspective of the third person. Preemptive pedagogy entails seeing the self as prey caught in the trap set by the predator. 
In order to anticipate the reactions of his pursuers, Gregoire Chamayou argues that "the hunted man has to learn to interpret his own actions from the point of view of the predator which entails...seeing himself in the third person, considering, with respect to each of his acts, how they might be used against him" (2012: 70).

Adopting the view of the predator extends beyond adopting the ontology of the human adversary to include all Achimota City's soldierly species such as the snakes that fight Torro's rats and the crows that attack Roman mercenaries in the "battle on the ground and the battle of the wings" (Laing 1992: 176). Understanding the self as prey entails a training in the ontology of the enemy that can "later be transformed into reasoning" (Chamayou 2012: 70). But how and in what ways is this training transformed into reason? And how do its implications ramify across the chains of command that extend the infrastructures of feeling that compose Achimota City? The soldier in the line of command experiences the "transformation into reasoning" as the command to practice perversely paradoxical strategies. Much to the consternation of the Shadow Commander Zero, the Elders appoint Torro to the post of Minister of Defence: "But Major, the whole plan is confusing me! Do I plan with him or against him? Does he get to know everything and then use the information against us? Major, help me!" (Laing 1992: 99).

The paradoxical plan traps poor Commander Zero in the cybernetic condition of the double bind. The shadow commander's inability to plan a future based upon a present action whose outcome will destroy its present confronts it with the uncomfortable experience of being trapped by its own reasoning. The major does not resolve the pain of paradox. Instead, he personifies it "with a faraway look in his small face" by replying "Commander, here we don't solve paradoxes, we just win wars..." (ibid). Major Gentl's enigmatic reply forces the shadow Commander to confront the ways in which the capacity to plan the future threatens to destroy the present that is its precondition for existence. Commander Zero's paralysis enacts the first phase in the pedagogy of preemption. Major Gentl's riddling response returns to and develops the paradoxical praxis of a soldier who is feared "for his gentleness" (ibid: 1). If Torro is the noise that often distorts the enemy's signal, then Gentl is the amplifier that boosts the noise that is Torro and Mr Cee is the transducer that converts the physical phenomena of noise into electrical signals. Like Major Gentl, the Cockroach does not solve paradoxes. Instead it transduces them. As it explains to Pogo Alonka Forr: "We are with you here if you care to listen, Alonka Forr', said the golden cee, correcting Pogo's eyes. Maybe if we tell you what we think, then we can help you answer our own questions..." (ibid: 130).

This sly suggestion provides a diagram of the cybernetic operations carried out by the Cockroach on the City throughout the seventeen zones of the Achimota Wars. Training the City to adopt the ontology of the enemy by taking the third decision and seeing oneself from the triple view does not entail assuming the position of the victim. Instead, it locates both roles in a co-constitutive process of mutual implica- 
tion. It diagrams ways of preventing the unwanted effects of a future by causing that future in the present. Because it was an object before it became a creature, a flag before it became a cockroach and an emblem before it became a thing, the Golden Cockroach is well suited to transduce the signals it receives in the form of messages into the force of laughter that it transmits. The cockroach is the figure of transduction. A figure that continually freezes in front of its interlocutors. And as it does so, it catches the reader in the act of laughing. The garrulous Golden Cockroach laughs "its tiny laugh like a jug that it used to pour scorn" on the gold horseriding, helicopter flying Pogo Forr and the obsessive Nana Mai the Grandmother Bomb and Delali, the conversational wife of Pogo Forr, the rabbit eared Elder Chairman Kofi Kot, and the argumentative Elder Two Jojo Dogi and the bigitive Elder Three Amos Kittoe and the flexible Ama Three and the snake-loving Major Gentl and the lovelorn Bianca and the uproarious Torro the Goro and the riceobsessed General Jolloff and the shadow saxophone playing deputy minister of defence Commander Zero and the Torro's shadow deputy Tallberto and the taciturn Captain Owusu and the drunkard Abomu Kwame and the precocious Baby Sama and the insolent Government Crow and the official Government Goat and the mathematician Professor Dolla and the trumpeter Jollo Gyan and the wrecked Ship of Truth and the bronze GOAT OF MERCY and the mathematical parrot named Koo and the faithful silver mosquito and the devoted silver owl (ibid: 129). Its laughter is triangulated by the third presence of the reader that continually adjusts to the shifting poetry of scale.

...Look at the doubt in the face of the gatherer of shadows.

LAING 1992: 100

\section{WE DON'T SOLVE PARAdoXeS}

The circuit that Mr Cee articulates for Pogo Forr is the diagram that reconstructs the process by which the creatures of Achimota City learn to navigate the seventeen zones of the War of Existence. To read Mr Cee's diagram is to recursively grasp the ways in which the future of Achimota City has been guiding the present of reading. To read with Mr Cee's circuit is to assemble the path by which the magical converges with and collapses onto the circuit of the cybernetic. To read the golden cockroach's diagram is to follow the proxy as it feeds forward into the paradoxical. To read its golden paradox is to feed forward into the predictive as it meets the preemptive arriving from the other side of the circuit. Reading with the zones of Major Gentl and the Achimota Wars entails taking seriously a laughter that is hom- 
onymic, alliterative, grammatical, phallic, predicative, virtuosic, grotesque, and ontogenetic. Reading with Laingian disestablishmentarianicism requires a movement in and with the thought of the Second War of Existence outside of its text, beyond the life, and after the passing of Bernard Kojo Laing. Reading with and for the desedimentation of the Wars of Existence requires a reading that moves in the time of the antecedent in order to move in the time of the prospective. Reading with the Wars of Existence entails an operation of desedimention that persists into the presences of the present, continues into the futurities of the future, and will have existed in the histories to come. Rereading the existence of Achimota City requires the relinquishment of genre specificity. Rereading the relinquishment of genre specificity confronts one with the ways in which the City makes trouble for generic claims upon its existence. To read with the trouble of the Laingian City is to read the ways in which the trouble of the Laingian text is a problem and a possibility for African literature, African futurity, African science fiction, African speculative fiction, Pan-Africanism, and Afropolitanism. To read with Laingian possibility is to mobilize the ways in which Laingian grammar problematizes the systems of predicates by which Africanity, futurity, literature, science, speculation, and fiction will exist and have existed and are existing. To read with Laingian Africanity is to think the ways in which the Laingian thought of the African metropolis prefigures and reconfigures the speculative urbanism of the Afropolitan condition.

Reading Major Gentl and the Achimota Wars as a post-Afropolitanist text entails the commitment to upgrade the unrealized ambition of continental Pan-Africanism not as a dream or as a lament but as a contemporary speculation on unedited history. Rereading the Second War of Existence as a fiction for universal conscription demands the reconfiguration of Wrightian militarization before and after the cybernetic science of total war. Reading the Laingian text as a fable of totalitarianism necessitates the rereading of the notion of the magical in the terminology of the total artwork. Rereading the magical in the Laingian text as an extension of the project of aesthetic dictatorship indicates the necessity of rethinking the relation between text and totality, form and force, fiction and servitude, futurity and virtuosity. To reread Laingian grammar in terms of the diagrams of cybernetics is to open the circuit between the engineering of temporality, the temporality of war, and the theatre of warfare as the ontology of enmity and the becoming of adversity. To reread the seventeen zones of Major Gentl and the Achimota Wars is to pass from the principle of the proxy to the pedagogy of paradox to the praxis of prediction to the poetry of preemption. To read the Laingian text is to reread the magical in its syntax of becoming. To read the Laingian syntax of becoming is to encounter the Laingian poetics of inventivism. To reread the Laingian poesis of inventivism is to confront the Laingian composition of the 'ludicrum'. To reread the Laingian confabulation of the ludicrum is to convoke the Laingian exactitude of 'nkwasiem'. To read the 
22 | Kodwo EsHun

Laingian exorbitance of nkwasiem is to encounter the Laingian fastidiousness of ontogenesis conducted in the Laingian recursion of ontological slapstick. 


\section{LITERATURE}

Adejunmobi, Moradewun (2016): "Introduction: African Science Fiction." In:

Cambridge Journal of Postcolonial Literary Inquiry 3/3 (Special Issue: African

Science Fiction) September, pp. 265- 272.

Chamayou, Gregoire (2012): Manhunts: A Philosophical History, Princeton and

Oxfordshire: Princeton University Press.

Chandler, Nahum Dmitri (2008): "Of Exorbitance: The Problem of the Negro as a

Problem for Thought.' In: Criticism, 50/33, pp. 353-354.

Chandler, Nahum Dmitri (2014): X - The Problem of The Negro as A Problem for

Thought, New York: Fordham University Press.

Cooper, Brenda (1998): Magical Realism in West African Fiction: Seeing with a

Third Eye, London: Routledge.

Deandrea, Pietro (1996): “'New Worlds, New Wholes': Kojo Laing's Narrative

Quest for Social Renewal.” In: Durosomi Jones, E. and Jones, M. (eds.), African

Literature Today 20, Africa World Press, pp. 158-178.

Derrida, Jacques (1982): Positions. Chicago: University of Chicago Press.

Dery, Mark (1994): "Black to the Future." In: Mark Dery (ed.) Flame Wars: The

Discourse of Cyberculture, Durham: Duke University Press, pp. 179-222.

Diop, Cheik Anta (1987): Black Africa: The Economic and Cultural Basis for a

Federated State, Chicago: Lawrence Hill Books.

Dukan, Menka-t Asli (n.d.): "Speculations...The making of the BBC's Black Sci-

Fi”. http://maslidukan.com/specs_blackscifi. Last Access 10.03.2017.

Enwezor, Okwui/Okeke-Agulu, Chika (eds.) (2011): Contemporary African Art since 1980, Bologna: Damiani.

Gaylard, Gerard (2005): After Colonialism: After Postmodernism and Magical Realism, Johannesburg: Wits University Press.

Groys, Boris (2008): Art Power, Cambridge/Massachusetts and London: The MIT

Press.

Groys, Boris (2011): The Total Art of Stalinism: Avant-Garde, Aesthetic Dictatorship, and Beyond, trans. Charles Rougle. London and New York: Verso.

Holert, Tom (2014): "National Heterologies: On the Materiality and Mediality of

Flags-Mali 2013." In: E-Flux Journal 52, http://www.e-

flux.com/journal/52/59923/national-heterologies-on-the-materiality-andmediality-of-flags-mali-2013. Last Access 11.06.2016.

Jameson, Frederic (2016): An American Utopia, Dual Power and the Universal Army, New York: Verso.

Klein, Tobias Robert (2007): "Kojo Laing and the Cultural Specifics of an African Modernity.” In: Klein, T.R., Ulrike Aufa and Viola Prüschenk (eds.), Texts, 
Tasks, and Theories (Versions and Subversions in African Literatures), Amsterdam/Atlanta: Rodopi, pp. 37-58.

Kourouma, Ahmadou (2004 [2001]): Waiting for the Wild Beasts to Vote, trans. Frank Wynne, London: Heinemann.

Levi-Strauss, Claude (1966): The Savage Mind, Chicago: University of Chicago Press.

Malec, Jennifer (2017): "Rest in Power, Pa Kojo: Paying Tribute to Kojo Laing." In: The Johannesburg Review of Books, May.

https://johannesburgreviewofbooks.com/2017/05/01/rest-in-power-pa-kojopaying-tribute-to-kojo-laing. Last Access 09.08.2018.

Marechera, Dambudzo (1980): Black Sunlight, London: Heinemann Books.

Marks, Laura U (2015): "Monad, Database, Remix: Manners of Unfolding in The Last Angel of History." Black Camera 6/2, pp. 112-134.

Massumi, Brian with Arne De Boever, Alex Murray and Jon Roffe (2009): "“Technical Mentality’ Revisited: Brian Massumi on Gilbert Simondon.” In: Parrhesia 7, pp. 36-45.

Mazrui, Ali A (1969): “The Monarchical Tendency in African Political Culture." In: Mazrui (ed.) Violence and Thought: Essays on Social Tensions in Africa London: Longmans, pp. 206-230.

Mbembe, Achille (2007): “Afropolitanism.” trans. Laurent Chauvet. In: Africa Remix: Contemporary Art of a Continent, Johannesburg Art Gallery, pp. 27-29. Naipaul, V. S. (1984): “The Crocodiles of Yamoussoukro.” In: Finding the Centre: Two Narratives, New York: Harper Collins, pp. 87-189.

Nkrumah, Kwame (1963): Africa Must Unite. London: Heinemann.

Nyerere, Julius (1997) “One Party-Government.” In: The Anniversary Issue: Selections from Transition, 1961-1976, Transition 75/76, pp. 156-161.

O'Connell, Hugh Charles (2016): "“We are change': The Novum as Event in Nnedi Okarofor's Lagoon.” In: Special Issue: African Science Fiction, Cambridge Journal of Postcolonial Literary Inquiry 3/3, pp. 265-272.

Padmore, George (1956): Pan-Africanism or Communism: The Coming Struggle for Africa, London: Dennis Dobson.

Ryman, Geoff (2017): “The Hazy, Hurried Thoughts of a Westerner on the Death of B Kojo Laing.” In: The Johannesburg Review of Books, May 1.

Simone, AbdouMaliq (2004) "People as Infrastructure: Intersecting Fragments in Johannesburg." In: Public Culture 16/3, pp. 407-429.

Singh, Nikhil (2016): "Kojo Laing's Major Gentl and the Achimota Wars." In: The Chronic: The Corpse Exhibition and Older Graphic Stories, Cape Town: Chimurenga, pp. 26-29. 
Tansi, Sony Labou (2011 [1979]): Life and a Half, trans. Alison Dundy, Bloomington: Indiana University Press.

Thiong'o, Ngũgĩ wa (2006): Wizard of the Crow, London: Harvill Secker.

Nelson, Raymond (ed.) (1999): 'Harlem Gallery' and other Poems of Melvin B. Tolson, Charlottesville and London: University Press of Virginia.

Wainaina, Binyavanga (2011): "Introduction.” In: B. Kojo Laing (2011[1986]): Search Sweet Country, San Francisco: McSweeney's Books, pp. vii-xvi.

Waberi, Abdouramane (2009): In the United States of Africa, trans. David and Nicole Ball, Lincoln: University of Nebraska Press.

Williams, Raymond (1977): Marxism and Literature, Oxford: Oxford University Press.

Wenzel, Jennifer (2014): "Petro-Magic-Realism Revisited: Unimagining and Reimagining the Niger Delta" In: Ross, B. and Worden, D. (eds.) Oil Culture, Minneapolis: University of Minnesota Press, pp. 211 -225.

Wollen, Peter (1999): "Stalin at the Movies.” In: London Review of Books 21/23, pp. 21-24.

Wright, Derek (1997): "Postmodernism as Realism: Magic History in Recent West African Fiction.” In: Wright, Derek (ed.) Contemporary African Fiction, Bayreuth: African Studies, pp. 181-207.

Wright, Richard (2008): Black Power: A Record of Reactions in a Land of Pathos, New York: Harper Perennial.

\section{FILMS}

Black Sci-Fi, Terrance Francis, BBC2, 1992. 